\title{
Features of Business Process Reengineering and Possessory Risk Management in the Context of Innovation Economic Development
}

\author{
Mikhail Vladimirovich Khachaturyan ${ }^{1}$, Evgeniia Valerievna Klicheva ${ }^{2,}{ }^{*}$, and Vladimir Viktorovich \\ Velikorossov ${ }^{3}$ \\ ${ }^{1}$ Candidate of Economic Sciences, Associate Professor, Associate Professor of Department of \\ Organizational and Managerial Innovations, Plekhanov Russian University of Economics, Moscow, \\ Russia \\ ${ }^{2}$ Candidate of Economic Sciences, Associate Professor, Associate Professor of the Restaurant \\ Business Department of the Plekhanov Russian University of Economics, Moscow, Russia \\ ${ }^{3}$ Doctor of Economic Sciences, Professor, Head of Department of Organizational and Managerial \\ Innovations, Plekhanov Russian University of Economics, Moscow, Russia \\ *Corresponding author
}

Keywords: Features, Reengineering, Business Processes, Possessory Risk Management, Innovation, Economic Development.

Abstract: The paper is devoted to the analysis of features of business process reengineering and possessory risk management in the context of innovation development of the economy. The paper discusses the specifics of the creation and development of possessory risk management systems in modern conditions. New models of risk analysis, assessment, organization, regulation, and management are created in the process of functioning of organizations and entrepreneurs, business consultants, and professional service firms.

\section{Introduction}

The present stage of economic development is marked by worsening problems associated with business management inefficiencies.

Therefore, increasing economic sustainability and maintaining competitiveness in market conditions is one of the main tasks that are solved when establishing a new enterprise or in the course of management of the existing enterprise. Hence, there is the objective need in search and implementation of new management tools that meet current market conditions.

In this connection, to improve the adequacy of the national vocational education system to the requirements of the knowledge-based market economy, not only training personnel with new competencies is required but also creating a powerful source of innovative ideas and technology.

The enhancement of research and innovation components in high schools will allow them to take the position of leading platforms for: 
- Outsourcing research activities for companies in the real economy;

- Generating applied ideas and developments as well as creating an innovative intellectual environment;

- Promoting innovative entrepreneurship;

- Transferring the sources of the highest-quality and competent examination of applied scientific and technological solutions for business;

- Providing consulting services and consulting support of predominantly interdisciplinary profile for a wide range of enterprises.

Therefore, it can be noted that building a rational business system, key economic parameters management, considering changes in the external and internal environment, and development of measures to improve business performance can only be achieved through the integration of consulting activities with modern higher education within the basic national research and innovation system in Russia.

\section{An Analysis of Mechanisms for Assessing an Organization's Ability to Generate Value at the Present Stage}

According to the logic of the modern development stage of the Russian economy, the risk management system is the key element determining the ability of the organization's management system to generate value for company owners and consumers of its products. However, the problem of creating and improving a risk management system in modern conditions is relevant not only for top managers and owners of private companies but also for representatives of the highest-level management of the national economy. The challenge of theoretical and practical understanding of the problems of possessory risks and business processes reengineering gains importance in consulting and education.

It should be noted that the theoretical discussion of the need to improve the possessory risk management, as well as the practical implementation of measures aimed at solving this problem, is the reflection of the lack of an effective relationship between management science and management practice both at the level of private companies and at the state level. On the one hand, in the environment of prices reduction for Russian traditional export goods groups and the economic sanctions, emerged a functional and political need to support and develop economic monitoring and management mechanisms. It is obvious that the economic situation is such that the main types of possessory risks, which are inherent in both private company and national economy, shall be identified, edited, and managed in an efficient and timely manner.

On the other hand, these factors have a serious impact on the functional stability of Russian companies of all forms of ownership various sectors of the economy, while creating conditions, under which unstable position of an enterprise in one sector can lead to negative consequences for other sectors of the economy, generating a consistent flow of failures, scandals, and catastrophes, which can lead to the collapse of the organizational and economic mechanism of the national economy management, with a complete lack of understanding of the essence of risks and threats, as well as their management mechanisms, both among top managers and owners of companies and from the government authorities.

Therefore, we can conclude that the possessory risk management system in modern conditions is intended to organize that which cannot be organized as part of the regular management system that has existed until now. Developing ownership risk management systems is the key to the successful implementation of innovation projects, both private and public. Thereby, such development not only imposes new requirements on the responsibility of owners and top managers for their decisions, 
which must be implemented in situations previously being potentially unsolvable, but also provides new ways to evaluate the effectiveness of these decisions.

\section{Change of Trend of the Implementation of Business Process Reengineering and Possessory Risk Management Programs}

Today, there is an obvious trend where companies that have traditionally taken risks on behalf of the public, such as insurance companies, hedge funds, financial corporations, prefer to incorporate public risks as an integral part of their internal possessory risk management systems.

According to the authors, this process is the evidence of a gradual transition from the possessory risk management system, which is based on the separation of customer risk and risk management mechanisms (quite effective but vulnerable in modern environment) towards merging these two mechanisms into a single risk management system for the organization's owner and customer.

Under current conditions, the risk management system should also be transformed at the national level. Development of risk management systems for the economic security of Russian in the modern world takes the key role in maintaining the economic system stability and the transition to economic growth. Federal and regional authorities shall solve the triple problem of preventing, managing, and redistributing risks. It should be noted that, without solving this problem, we cannot talk about building effective systems of organization possessory management or about improving the system of governmental management of the economy.

It is important to stress that the possessory risk management is much more critical for business development than a mere mechanism for technical and analytical assessment of challenges and threats to be addressed in the organization life cycle. Today, the possessory risk management system also serves as the embodiment of key values and ideals of management in general and, last but not least, of values and ideals of accountability and responsibility. Historically, the main goal of developing and implementing the organization's policy in the field of possessory risk management was to ensure the transparency and accountability of scientific expertise of decisions on the acceptability of certain risk levels. However, at the end of the $20^{\text {th }}$ century and in the first third of the $21^{\text {st }}$ century, the need to create and develop possessory risk management systems increasingly takes up a significant part of the set of mechanisms for possessory management of major multinational companies and, in certain periods, such need becomes its defining element. Therefore, mechanisms of risk analysis, assessment, and management, which until now have traditionally had a technical value for achieving the goals set for an organization, have become a key element of the organization possessory management system and the state regulation of the economy under conditions of economic instability.

\section{Conclusion}

It is also obvious that problems of building and developing an effective risk management system and the related issues of business process reengineering are of great interest for both the consulting sector and the education. As part of the integration of consulting and education, the key task to fulfill is addressing the need in theoretical and practical understanding of the above problems and elaborating a unified concept of introduction of joint developments in management practice.

\section{References}

[1] Christensen, C (1997). The Innovator's Dilemma: When New Technologies Cause Great Firms to Fail. Boston, MA: Harvard Business School Press. 
[2] Sakharchuk Natalia S., Moseykin Yury N. (2018) Conceptual Approaches to the Role of Education in the Formation of a Modern Business Community in Russia. Proceedings of the $4^{\text {th }}$ EER International Conference on Social Sciences and Interdisciplinary Studies (EER-SSIS 2018) Palermo, Sicily, Italy August 18-20. P. 130-135.

[3] Koryagina I.A., Khachaturyan M.V., Klicheva E.V. (2018). Development of mechanisms of value creation and risk management organization in the conditions of transformation of the economy of Russia. International Journal of Social, Behavioral, Educational, Economic, Business, and Industrial Engineering. Vol. 12. No. 1. P. 44-48.

[4] Goncharenko L.P., Sybachin S. A., Khachaturyan M. V. Peculiarities of Organizational Economic Mechanism Development in correspondence with State Strategic Management in Russia. Proceedings of Conference Trends of Technologies and Innovations in Economic and Social Studies (TTIESS 2017). Advances in Economics, Business, and Management Research, Vol. 38, 2017. Atlantis Press, 2017.

[5] Denisov I.V., Khachaturyan M.V., Umnova M.G. (2018) Corporate Social Responsibility in Russian Companies: Introduction of Social Audit as Assurance of Quality. Quality - Access to Success. Vol. 19. Vol. 164. P. 63-73.

[6] Khachaturyan M.V., Klicheva E.V. (2018) The features of the relationship of developing the possessory risk management systems and ensuring the economic stability of the organization. Proceedings of the $4^{\text {th }}$ EER International Conference on Social Sciences and Interdisciplinary Studies (EER-SSIS 2018) Palermo, Sicily, Italy August 18-20. P. 35-47.

[7] Khachaturyan M.V., Klicheva E.V., Velikorossov V. V. (2019) Digital Mechanisms of Development of Possessory Risk Management Systems under New Economic Conditions. Proceedings of the 2019 International Conference on Politics, Economics and Management (ICPEM 2019). Lecture Notes in Economics, Management, and Social Sciences. Clausius Scientific Press, Vol. 5. P. 6-10. 